\title{
IMPACT OF TRADE ON ECONOMIC GROWTH OF PAKISTAN: AN ARDL TO CO-INTEGRATION APPROACH
}

\author{
Nooreen Mujahid ${ }^{*}$ \\ Azeema Begum ${ }^{* *}$ \\ Muhammad Noman
}

\begin{abstract}
This paper explores the relationship between export growth and economic growth in the case of Pakistan by employing time series data for the period 1971-2013. This study has incorporated variables like GDP (Gross Domestic Product) exports, imports and Foreign Direct Investment (FDI). We have applied ARDL to co-integration and Error Correction Model (ECM). The study provides the evidence of stationary time series variables, the existence of the long - run relationship between them, and the result of ECM revealed short rum equilibrium adjustment. Pakistan has many options for enhancing the export of the country. There is a dire need to minimize trade barriers and restrictions such as import and export quotas. Government of Pakistan had introduced Structural Reforms for liberalization, privatization and de-regulation which will actually shifted the trend of trade at a significant level in the end of 1980s. Low levels of interest rate can help exportable industries in which investments are needed to promote and enhance the exports. Stable exchange rate is the first and the best policy option for increasing the export and managing the imports. There is a cause and effect relationship between exchange rate and FDI. Pakistan has to immediately find the policies and processes that support logistics and facilitates trade.
\end{abstract}

Keywords: Export, FDI, import, economic growth and ARDL

\section{JEL Classification}

\section{Introduction}

Increase in exports always plays a vital role to improve the growth of any country. Growth of the economy is based on many factors which accelerate the pace of economic development. Export is an essential macroeconomic variable which plays a vital role not only in the economic development but also for supporting balance of payment, improving the terms of trade and improves exchange rate.

Export-led growth theory reveals that growth in exports can help the economic growth and development of the nation. The theory articulates that the general development of economies does owe to increments in the capital stock, labor and in exports. The competitiveness in worldwide markets make competition difficult and challenging for

\footnotetext{
* Nooreen Mujahid, Ph.D. Assistant Professor, Department of Economics, University of Karachi.

**Azeema Begum, M Phil student, Department of Economics, University of Karachi.

${ }^{* * * *}$ Muhammad Noman,M.Phil student, Applied Economics Research Center, University of Karachi.
} 
the local producers. In this way, they adopt the new techniques and try to diminish different inefficiencies which exist in the local markets. Numerous studies, confirm the relationship between the exports and economic growth (Siddiqui, et al (2008), Alam (2011) and Shirazi and Manap (2005) etc).

Expansion of exports leads to an efficient distribution of resources, promotes economies of time and scale, enhancements in production strategies by augmenting learning and specialized base, augment global arrangements for the exchange of technology, aggregation and arrangement of capital and expansion in the labor markets. In developing nations, export promotion strategies are adopted to shrink deficit in the external sector. It aids the economic planners to guarantee about the scale and pace of an economic upturn.

The idea of openness of trade is from the classical school of thought and from the hypotheses of Adam Smith and David Ricardo. The hypothesis of International Trade stresses on the nexus between trade and globalization, which implies that the economic gains from specialization along with visible improvement in exports accelerate the amounts of GDP and hence increases national income. Accordingly, the chain effect starts by boosting the exports, earning foreign exchange and enhancing the balance of payment.

It is worth mentioning that openness of trade plays a pivotal role in economic growth, which is also associated with economic gains from specialization. Recently, the countries are stressing on the removal of trade barriers and restrictions which enhances their wellbeing position as compared to their closed economies.

The export-led growth hypothesis has been widely recognized (Feder, 1982 and Krueger, 1990) and advanced and transformed into a "new conventional wisdom" (Tyler, 1981; Balassa, 1985). It has also contributed in devising and developing numerous countries and the World Bank (World Bank Development Report, 1987).

The neoclassical perspective emphasizes that sustainable development might be attained by export led growth hypothesis. The success of emerging industrialized countries such as Hong Kong, Singapore, Korea, Taiwan, Malaysia and Thailand is because of the adoption of the above strategy while the most Latin America and Africa followed inward oriented, i.e. import substitution strategy and attained poor economic performance (Balassa, 1980). For the last three decades, these nations have multiplied their living standards at regular intervals. The experience of China during the 80s and 90s tend to backing the argument that trade openness is a strategy for attaining more efficient and rapid growth along with improved allocation of domestic resources (Findlay and Watson, 1996, p.4). Numerous studies contain comparable attestations for different nations and a few authors (e.g., Krueger, 1995) recognize trade strategy as the vital component of economic arrangement.

Pakistan has been trying to increase its export since independence. After the inception of Pakistan, in 1948-49 the exports of Pakistan comprised of only five items, in which jute, raw cotton, wool, hides and tea were included. However, the economic policies of the 1950s and 1960s were focused on industrialization that promoted the import substitution 
strategy, as its trade regime. Throughout the second half of 1970s, Pakistan's export growth was $10.6 \%$. In the first half of 1980s, Pakistan's exports were hardly increased, and rose only at $1.7 \%$ annually while the second half of 1980s, registered export growth rate of $11.6 \%$ per annum. During 1970-71 to 1984-85, export growth rose at the rate of $5.4 \%$ per annum, it has been recorded that export growth rate decreased from $27.1 \%$ to $1.7 \%$ while GDP growth rate increases from $5.03 \%$ to $6.27 \%$. On the other hand, during 1990-91 to 1999-00 export growth was decreased from 6.4\% to 3.0\%, along with the GDP growth rate from $4.21 \%$ to $3.36 \%$. Contrary, during 1995-96 to 2003-04 exports increased from $3.0 \%$ to $5.4 \%$, at the same time GDP growth also increased from $3.36 \%$ to $5.09 \%$ respectively. This result depicts that export has a very important role in the economic growth of Pakistan. Pakistan Domestic and Foreign Direct Investment (FDI) are essential for export industries as well as for the overall domestic economic growth. It generates employment opportunities, brings experts and specialists from the fields along with new technologies and has been an important component in extraordinary growth in international trade. For the last few years, Pakistan has been trying to attract the foreign investors in assets and portfolio investments. FDI is basically foreign investment in production and business in a host country, or is the net inflow of investment for acquiring the administration of the assets through more than $10 \%$ share of the asset. In 2001-2002, the FDI was \$485million which enlarged till 2007-2008 and reached \$5409 million and grown at 10 to $15 \%$ every year. However, after this peak FDI started to decline to $89 \%$ by the end of the 2011-2012. According to the State Bank of Pakistan, FDI in 2007 was $7.2 \%$ of GDP and reached to only $0.7 \%$ of GDP in 2012.

We have also used imports for analyzing the result of import to GDP growth. According to World Bank National Accounts data, imports as \% of GDP in Pakistan was $19.23 \%$ as of 2011. Its highest value over the past 44 years was $24.10 \%$ in 1980, while its lowest value was $12.79 \%$ in 1971. The annual growth of import was at a maximum in 1979 which was $47.99 \%$ and the minimum growth rate was $31.81 \%$ in 1972 . Our main concerned is export growth led hypothesis which defined that how increase or decrease in import plays a key role in GDP growth of the country by introducing some additional variables. FDI should be used for the promotion of export activity which not only increases the employment in the country, but also improves the shortfall of balance of payment and terms of trade and helpful in the appreciation of the exchange rate. Foreign Direct Investment should be utilized in those industries which take major part in exports. Consequently, it will promote exports and indirectly GDP. It demonstrates that Pakistan's potential FDI is much more as it directly enhances economic growth of the country. Pakistan's development strategy should include FDI as a crucial part in addition to export promotion strategy and imports. The imports are huge in volumes; it may comprise more on industrial goods. This paper will explore the long as well as a short term relationship among trade, FDI and GDP growth.

\section{Hypothesis of the study}

$\mathrm{H}_{0}$ : There is no relation among GDP and Export, Import, and FDI.

$\mathrm{H}_{1}$ : There is a relationship among GDP and Export, Import, and FDI. 


\section{Review of Literature}

Export led hypothesis have been examined by many researchers and it explains trade and economic policy with the aim to boost up the industrialization process by exporting the goods in which the country enjoys the comparative advantage. Export led growth implies open domestic market for foreign competitors and get an access in international market. This economic strategy has been adopted by many developing countries. After the great depression and Second World War, when every economy was closed for another, the import substitution policy had been adopted. In the 1950s and the 1960s, some Asian countries along with Taiwan and South Korea had focused export led growth for their development. And hence the emergence of Asian Tigers has supported the export led growth strategy for development.

Plenty of studies have highlighted the export led growth hypothesis in 1981. William G. Tyler (1981) has analyzed the empirical relationship between economic growth and export growth for the period of 1960 to 1977 from cross-section data of 55 middle income developing countries. He applied Vicariate tests and results shown the significant positive relations between growth and other economic variables in which the growth of manufacturing output, investment, total exports, and manufacturing exports are included. In the case of Pakistan, Khan et al (1995) tested this casualty for the period of 1972:II to 1994:II, using the Granger Causality Approach. They have found that there is a stable, long-run two-way relationship between exports and output, and the one-way stable relationship between output and primary exports. Moreover, they have found that there was a bi-directional relationship between exports of both primary and manufactured growth and economic growth. Ekanayake (1997) analyzed the causal relationship between export growth and economic growth in eight Asian developing countries using data from 1960 to 1997 for, Korea, India, Pakistan, Indonesia, Sri Lanka, Thailand and Malaysia by using co-integration and error-correction models. The results shown that bi-directional causality exists between export growth and economic growth in case of India, Indonesia, Korea, Pakistan, Philippines, Sri Lanka and Thailand. Furthermore, there was also evidence for export-led growth in Malaysia. Rahman and Mustafa (1997), test the causality of export and economic growth of 13 Asian countries including Bangladesh, India, and Pakistan etc. They used co-integration and ECM and determined that bidirectional causality between real GDP growth and real export growth have experienced by China, South Korea and Malaysia in both short and long run. But in case of Bangladesh, Thailand and Philippines there was an indication of bidirectional causality in the short-run and unidirectional causality in the long run from real export growth to real GDP growth. Moreover, Pakistan and Nepal have advantage from bidirectional causality in the short run while unidirectional causality in the long-run flows from real GDP growth to real export growth. India, Sri Lanka and Indonesia experience unidirectional causality from real GDP growth to real export growth in both the short and long run.

Anwer and Sampath (1997) investigated the relation and direction of export and economic growth of 96 countries by using unit root and co-integration techniques, from the period of 1960 to 1992 and only 8 countries showed unidirectional or bidirectional causality from exports to GDP with positive relationship between the two variables. 
Causality from GDP to exports with positive relationship between the two variables is found for only 9 countries. No long run relationship between the two variables was found for 30 countries; 20 countries shown causality at least in one direction, with unidirectional causality from GDP to exports for 12 countries, from exports to GDP for 6 countries and bidirectional causality for 2 countries; and 11 countries do not show any causality between GDP and exports. There are only 9 out of 96 countries which show positive impact of economic growth on exports.

Glasure (1999) have examined the export led hypothesis for Korea from 1973 to 1994 through Vector Autoregressive (VAR) model and Granger-causing export growth, regardless of the sample period. He had taken five variables, these were exchange rate, money supply, government expenditure and export as independent variable and economic growth as dependent variable. He found that results of the VECM show bidirectional causality between export growth and economic growth, and exchange rate fluctuations, money supply and government expenditure has also impact in economic growth. Dimkpah (2000) found the relationship of export and economic growth of 107 countries. He took average growth rate of the GDP as dependent variable between 1980 and 1990. The average growth rates of investment, population, and export for the same period were independent variables. The author used Investment as proxy for capital while population was used as a proxy for the labor force. He found that export growth is a positive contributor to economic development of low income countries as well as middle income countries. The impact is stronger in middle-income countries than in low income countries. Quddus and Saeed (2005) have examined the causality between export and economic growth in case of Pakistan for 1970-71 to 2003-04.They had taken three variables export, investment and GDP in real term and used the Unit Roots and Co-integration and Granger Causality for testing. Granger Causal relationship running from export to economic growth was suggested by the test results. Their study rejected the hypothesis exports and GDP are not co-integrated and that export Granger cause GDP growth.

Konya and Singh (2006) have investigated the impact of export and import in economic growth for India. The variables incorporated are export and import as independent variables and GDP as dependent variable for1951 to 2004. Co-integration and ECM technique has been used. Shamsaad and Shamhudeen (2007) investigated the effect of exports on economic growth in Bangladesh, which was based on a two-sector growth model. Using annual data for 1961-92, and used an ARCH model of economic growth. They suggested that an increase in the share of investment in GDP significantly increases the growth rate of GDP and export growth has significantly increased economic growth through its positive impact on total factor productivity in the economy. The contribution of exports to economic growth was more prominent during 1982-90.

Bahamni et al (2007) found the short run and long run relationship of export and economic growth for 44 countries.They have used Bound test method and ECM for testing the result. They have found that majority of the countries have short run effect of export in econmic growth in both direction while in long run, $60 \%$ export led hypothesis is supported and $40 \%$ output led hypothsis is supported in the above mentioned study. 
Siddiqui et al (2008) re-investigated the causality between export and economic growth in case of Pakistan. They have used more than two variables exports, imports, terms of trade, and the labor force participation rate as explanatory variables and GDP as the dependent variable for 1971-2005 and used the more broad and recent bounds test or ARDL. They found that exports, labor force, and imports have a positive effect on economic growth; however terms of trade has a negative effect. The trade liberalization has a positive impact on economic growth.

Dash (2009) examined the export led growth hypothesis for India and used cointegration and ECM to analyzed the causal relationship between export growth and economic growth in India for post-liberalization period (1992[Q1]-2007[Q4]). He found the result which indicates that a long-term relationship exists between output and exports and it was unidirectional, from exports to output growth. Alam (2010) studied the export led hypothesis in case of Pakistan for the period of twenty seven years (19712007) used quarterly time series. This study has applied the co-integration technique and ECM to investigate the relationship among the export, import and GDP growth. He found that there is positive relationship between economic growth, import and export. Imports and Exports are positively related with independent variable GDP. Although in the short run, the result of ECM showed the short run impacts of independent variables such as import and export on the dependent variable economic growth.

Mishra (2010) studied the relationship between export and output for 1970 to 2009 for India and applying time series econometric techniques of co-integration and VECM. He found the confirmation of stationary of time series variables, and revealed the existence of long-run equilibrium relation between them. However, he rejected the export led growth hypothesis by the Granger causality test which was based on VECM estimation for India. Further he also found some empirical proof that the long-term trend maynot be exports-led growth in India. Temizet al (2010) investigated the relationship of real export and economic growth which was represented by real GDP by using time series data for the period 1950-2006 for Turkey. This study uses famous ADF unit root test, Johansen co-integration test, VECM, and Granger causality test. The result revealed that there is a long run and short run causality relationship between the real export and the economic growth and the direction of the causality is from economic growth (real GDP) to real export.

\section{Data Sources and Methodology}

\section{Data}

In this study the time series data for 30 years has been employed for the period 19812010. The data is taken from United Nations Conference on Trade and Development (UNCTAD). The main variablesare FDI, Export, GDP and import. GDP is dependent variable and export, FDI, import are the independent variables. The GDP, Export Import and FDI are in millions of US \$ and all data are in nominal values. We have taken growth model and our main objective is to find the relationship of GDP and export from 1981 to 2010 for Pakistan. The prime consideration is to explore the relationship of GDP with export, import and FDI. We expect FDI, Export has expected positive signs, but import has negative. 


\section{Methodology}

In the first step one has to check the stationary of the data for that reason Augmented Dickey-Fuller test is developed by Dickey-Fuller (1979). After accessing ADF test, ARDL to co-integration technique is suitable for this model. In the second step we try to find a long run relationship among GDP, export, FDI and import through applying ARDL to co-integration developed by Pesaran and Shin (1999) and ECM developed by Engle and Granger (1987). There are many previous researches in which these tests had been applied especially to check the long run equilibrium condition. This econometric technique is used due to simplicity and relevance in time series data, ability to ensure the stationary and provide the confirmation about long as well as short run association among the said variables. For applying ARDL approach and to avoid spurious results all variables which are taken need to be stationary. Time series data are stationary when the mean, variance and covariance are remaining constant. This can be checked by the Augmented Dickey-Fuller test (ADF). All variables are taken in log form. The Akaie Information Criterion (AIC), Schwarz Criterion (SC) and the Likelihood Ratio (LR) test are used to select the number of lags required in the ARDL test. If long run cointegration is proved then we move to test the short run equilibrium relationship. The main objective of ECM is it checks the speed of adjustment from short run to long run. The greater value of coefficient of error correction term, the higher the speed of adjustment of the model it will be.

\section{Modeling Framework:}

\section{GDP $_{t}=\mathbf{f}\left(\right.$ EXPORT $_{t}$, IMPROT $_{t}$, FDI $\left._{t},\right)$}

$\mathbf{t}=1,2,3 \ldots \mathrm{n}($ time period from $1971-2013)$

GDP= Gross Domestic Product (for measuring the economic growth) in time t

EXPORT= export (for measuring the EXPORT led growth)

$\mathbf{F D I}_{\mathbf{t}}=$ Foreign Direct Investment

IMPORT $_{\mathbf{t}=}$ import of the country

$$
\operatorname{LOG}(\text { GDP })_{t}=\alpha_{o}+\beta_{1} \operatorname{LOG}(\text { FDI })_{t}+\beta_{2} \operatorname{LOG}(\text { EXP })_{t}+\beta_{3}(\text { IMP })_{t}+e_{t}
$$

Where $=\alpha_{0}$ is intercept and $\beta_{1}, \beta_{2}, \beta_{3}$ are the coefficient of FDI EXPORT and IMPROT respectively. $\mathbf{e}_{\mathbf{t}}$ is residual term.

\section{1) Result and Discussion:}

The empirical results are as follows: 
Table No. 1 Descriptive Statistics

\begin{tabular}{|l|c|c|c|c|}
\hline & LGDP & LEX & LIM & LFDI \\
\hline Mean & 10.97197 & 8.511691 & 8.958026 & 5.344941 \\
\hline Median & 11.09721 & 8.826558 & 9.055042 & 5.724891 \\
\hline Maximum & 11.89735 & 10.11900 & 10.71246 & 8.596041 \\
\hline Minimum & 9.911308 & 6.459122 & 6.495266 & -0.693147 \\
\hline Std. Dev. & 0.613348 & 1.054375 & 1.057808 & 2.043588 \\
\hline Skewness & -0.253306 & -0.360760 & -0.353758 & -0.582240 \\
\hline Kurtosis & 1.830421 & 2.043065 & 2.806977 & 3.202221 \\
\hline Jarque-Bera & 2.910689 & 2.573402 & 0.963623 & 2.502789 \\
\hline Probability & 0.233320 & 0.276180 & 0.617663 & 0.286106 \\
\hline Sum & 471.7945 & 366.0027 & 385.1951 & 229.8325 \\
\hline Sum Sq. Dev. & 15.80024 & 46.69168 & 46.99622 & 175.4026 \\
\hline Observations & 43 & 43 & 43 & 43 \\
\hline
\end{tabular}

Source: Estimated and tabulated by Authors

The descriptive statistics are explained in table no. 1. The outcomes depict that all the series have homoscedastic variance and normal distribution as indicated by Jarque-Bera statistics.

Table No. 2 Unit Root Test (ADF)

\begin{tabular}{|l|c|c|c|c|}
\hline Variables & $\begin{array}{c}\text { Calculated } \\
\text { value }\end{array}$ & $\begin{array}{c}1 \% \text { Critical } \\
\text { value }\end{array}$ & $\begin{array}{c}5 \% \text { Critical } \\
\text { value }\end{array}$ & Probability \\
\hline LGDP (1) & -1.151056 & -4.198503 & -3.523623 & 0.9073 \\
\hline D(LGDP) (0) & -5.521332 & -4.198503 & -3.523623 & 0.0003 \\
\hline LEX (0) & -1.676161 & -4.192337 & -3.520787 & 0.7442 \\
\hline D(LEX)(1) & -5.097338 & -4.205004 & -3.526609 & 0.0009 \\
\hline LIM(4) & -3.186678 & -4.219126 & -3.533083 & 0.1023 \\
\hline D(LIM)(0) & -5.746559 & -4.198503 & -3.523623 & 0.0001 \\
\hline LFDI(5) & -2.248872 & -4.226815 & -3.536601 & 0.4500 \\
\hline D(LFDI)(4) & -3.699037 & -4.226815 & -3.536601 & 0.0349 \\
\hline
\end{tabular}

Source: Estimated and tabulated by Authors

"Notes: $\mathrm{Y}$ : The Level form of the variable $\mathrm{Y}, \Delta(\mathrm{Y})$ : The first difference of the variable Y. $\Delta(\mathrm{Y}, 2)$ : The second difference of the variable Y."

ADF test reveal that the selected variables are found to be non-stationary at level with intercept and trend. At $1^{\text {st }}$ difference, all the variables become stationary. It is concluded that the variables are integrated at I (1) confirmed by ADF test. 
Table No. 3 Autoregressive Distributed Lag Estimates

\begin{tabular}{|l|l|l|r|}
\hline Regressors & \multicolumn{1}{|c|}{ Coefficient } & \multicolumn{1}{|c|}{ Standard Error } & T-Ratio[Prob] \\
\hline LGDP(-1) & 0.88885 & 0.074616 & $11.9123[.000]$ \\
\hline LEX & 0.050538 & 0.029573 & $1.7090[.096]$ \\
\hline LIM & 0.013455 & 0.015697 & $0.85719[.397]$ \\
\hline LFDI & -0.0045435 & 0.0060473 & $-0.75133[.457]$ \\
\hline CONSTANT & 0.72423 & 0.65929 & $1.0985[.279]$ \\
\hline TREND & $0.4817 \mathrm{E}-3$ & 0.0024771 & $0.19447[.847]$ \\
\hline R2 & 0.99913 & Heteroscedasticity & $1.6178[.211]$ \\
\hline Adjusted R2 & 0.99901 & F-stat. (5, 36) & $8260.7[.000]$ \\
\hline DW-statistic & 1.6963 & Serial Correlation & $0.49194[.488]$ \\
\hline
\end{tabular}

Source: Estimated and tabulated by Authors

ARDL approach to Integration technique demonstrates that the entire chosen variables have a long-term association with F-stat. 8260.7 and p-value 0.000 .

Table No. 4 Estimated Long Run Coefficients using the ARDL Approach

\begin{tabular}{|l|c|c|r|}
\hline Regressors & Coefficient & Standard Error & T-Ratio [Prob] \\
\hline LEX & 0.45467 & 0.21707 & $2.0946[.043]$ \\
\hline LIM & 0.12105 & 0.71868 & $0.6126[0.573]$ \\
\hline LFDI & -0.040876 & 0.071868 & $-0.5687[.573]$ \\
\hline CONS & 6.5156 & 1.8134 & $3.5929[0.001]$ \\
\hline TREND & 0.004334 & 0.019848 & $0.2183[0.828]$ \\
\hline
\end{tabular}

Source: Estimated and tabulated by Authors

The table above demonstrates the estimated long-term coefficients using an ARDL approach to cointegration, which illustrates that GDP growth rate is very much influenced only with export in the long run. There is a positive or direct association among export and; this association is statistically significant at 5\%. 
Table No. 5 Error Correction Representation for the Selected ARDL Model

\begin{tabular}{|l|l|l|r|}
\hline Regressors & \multicolumn{1}{|c|}{ Coefficient } & \multicolumn{1}{|c|}{ Standard Error } & T-Ratio[Prob] \\
\hline $\mathrm{D}($ LEX) & 0.050538 & 0.029573 & $1.7090[.096]$ \\
\hline $\mathrm{D}(\mathrm{LIM})$ & 0.013455 & 0.015697 & $0.85719[.397]$ \\
\hline $\mathrm{D}(\mathrm{LFDI})$ & -0.0045435 & 0.0060473 & $-0.75133[.457]$ \\
\hline $\mathrm{D}(\mathrm{CONS})$ & 0.72423 & 0.65929 & $1.0985[.279]$ \\
\hline $\mathrm{D}(\mathrm{TREND})$ & $0.4817 \mathrm{E}-3$ & 0.0024771 & $.19447[.847]$ \\
\hline ECT $_{-1}$ & -0.11115 & 0.074616 & $-1.4897[.145]$ \\
\hline R2 & 0.28824 & F-stat. & $2.9158[.026]$ \\
\hline Adjusted R2 & 0.18938 & DW-statistic & 1.6963 \\
\hline
\end{tabular}

Source: Estimated and tabulated by Authors

In the short-term analysis, The ECT has a sign consistent with econometric theory and it is significant at $14.5 \%$. The extent of coefficient of ECT makes obvious the speed of variation from short-term to the long-term path.

\section{Conclusions and Policy Implications}

This study re-investigated the relationship between exports and economic growth in Pakistan with variables like FDI and import. The results of the ARDL to co-integration test indicate the existence of the co-integration between two variables and have a long run equilibrium relationship. They may be in disequilibrium in the short-run. The independent variables such as imports and exports are positively related with GDP. Therefore, the government should make efforts and take steps to enhance the exports as well as imports in order to promote economic growth. There should be no trade barriers in the form of import and export quotas and tariffs or some other kind of trade restrictions. The import should be based on more capital goods which could contribute to increase more production of goods. While exports should be based on more manufacturing goods rather than the primary good which have low terms of trade.

Due to high trend of consumption, Pakistan is trying to attract foreign and direct investment in the country. FDI can contribute to increase the GDP growth because it shows significant values. Government of Pakistan can adopt more transparent Structural Reforms to accelerate and expedite liberalization, privatization and de-regulation activities within the country. In order to facilitate the investment activities protective duties/taxes on the industry should be removed to promote competition and raise exports. For the last few months, due to low level of inflation, expansionary monetary policy is being followed which can reduce the cost of production and increases the competitiveness of exports. Low levels of interest rate can help those industries in which investment is needed to promote and enhanced the export industries. Stable exchange rates are the first and the best policy options for the increase in exports and manage the imports. Exchange rate also encourages the FDI in both terms, whether increasing or decreasing. The costs which is imposed behind the border should be managed because it 
declines the competitiveness of potential export. The transaction costs of export in developing countries are two to three times higher than that of the developed countries.Export diversification is broadly known as an encouraging trade policy for supporting economic growth. It helps to make countries less vulnerable to face the problems of terms of trade, shocks of export earnings and increase in returns to scale. Recently many developing countries are adopting product diversification policies to avoid expected or unexpected changes in term of trade.

\section{References}

Augmented-Dickey-Fuller (ADF) (Fuller and Dickey 1979)

Alam, H.M. (2011), An Econometric Analysis of Export - Led Growth Hypothesis: Reflections From Pakistan Interdisciplinary. Journal of Contemporary Research in Business, 2(12), 330-338.

Anwar, M., and R. Sampath, (2000) "Exports and Economic Growth", Indian Economic Journal, 47, 3, 79-88.

Ashfaque H. Khan, Afia Malik, and Lubna Hasan (1995)"Exports, Growth and Causality: An Application of Co-integration and Error-correction Modeling", The Pakistan Development Review, 34: 4 Part III, 1001-1012.

Balassa, B. (1980). "The process of industrial development and alternative development strategies", Princeton Essays in International Finance, No 141, December (Princeton, NJ: Princeton University, Department of Economics).

Balassa, B. (1985) "Exports, Policy Choices, and Economic Growth in Developing Countries after the 1973 Oil Shock". Journal of Development Economics, 4(1), 23-35.

Chow, P. C. Y., (1987) "Causality between Export Growth and Industrial Performance: Evidence from the NICs", Journal of Development Economics, vol. 26, pp. 55-63

E.M. Ekanayake (1999) "Exports and Economic Growth in Asian Developing Countries: Cointegration and Error-Correction Models", Journal of Economic Development, Volume 24, Number 2.

Engle, R.F., and C.W.J. Granger (1987) "Cointegration and Error-Correction: Representation, Estimation and Testing," Econometrica, Vol. 55, 251-276.

Feder, Gershon (1982), “on export and economic growth", Journal of Development Economics, Vol. 12, pp. 59- 73.

Findlay, C. and Watson, A. (1996) Economic growth and trade dependency in China, DP \# 96/5, Chinese Economics Research Centre, University of Adelaide.

Grossman, G.M., Krueger, A.B., 1995. Economic growth and the environment. Q. J. Econ. 110, 353-377.

Khan, A.H., and N. Saqib(1993) "Exports and Economic Growth: The Pakistan Experience", International Economic Journal, Vol. 7, No. 3, 55-64.s. 
Krueger, A. O. (1990). Foreign Trade Regimes and Economic Development: Liberalization Attempts and Consequences. Cambridge, MA: Ballinger.

Monica IoanaPopSilaghi(2009) "Export and economic growth causality Evidence from CCE countries", Romanian Journal of Economic Forecasting, Volume 2.

Muhammad Azam (2010) "Exports and Economic Growth in Pakistan: An Empirical Analysis", Journal of Managerial Sciences, Volume V, Number 2.

Muhammad S. Anwer and R.K. Sampath (1997) "Exports and Economic Growth" Presented at Western Agricultural Economics Association, 1997 Annual Meeting July 13-16, 1997 Reno/Sparks, Nevada.

Pesaran M H and Shin Y (1999) 'An Autoregressive Distributed Lag Modelling Approach to Cointegration Analysis' in S Strom, (ed.), Econometrics and Economic Theory in the 20th Century: The Ragnar Frisch Centennial Symposium, Cambridge: Cambridge U P.

Qazi Masood Ahmed, Mohammad Sabihudin Butt and Shasita Alam (2000)"Economic Growth, Export, and External Debt Causality: The Case of Asian Countries", The Pakistan Development Review 39: 4 Part II (Winter 2000) pp. 591-608.

Rahman, M., and M. Mustafa (1998) "Dynamics of Real Exports and Real Economic Growth in 13 Selected Asian Countries", Journal of Economic Development, Vol. 22, No. 2, 8195.

Rehman, Khan and Ahmad (2004) "Does Fischer Effect Exist in Pakistan A cointegrationAnalysis", Pakistan Economic and Social Survey, volume XLII".

Saima S. Sameena Z. Sadia M. and Sabihuddin M. B. (2008)“Export-Led Growth Hypothesis in Pakistan: A Reinvestigation Using the Bounds Test", The Lahore Journal of Economics, 13(2), 59-80.

Shirazi, Nasim Shah and Manap, Turkhan Ali Abdul, (2004), "Export-Led Growth Hypothesis: Further Econometric Evidence from South Asia." The Developing Economies, pp: 472-488.

Siddiqui, S., Zehra, S., Majeed, S., Butt. M. S., (2008), "Export-Led Growth Hypothesis in Pakistan: A Reinvestigation Using the Bounds Test", The Lahore Journal of Economics, pp: 59-80.

Tyler, W. G. (1981). "Growth and export expansion in developing countries: Some empirical evidence", Journal of Development Economics, 9, 1 (August): 121- 30.

Tyler, W.G. (1981), "Growth and Export Expansion in Developing Countries: Some Empirical Evidence", Journal of Development Economics, Vol. 9, No. 1, 121-130.

World Bank (1987), World Development Report 1987, New York: Oxford University Press. 